\title{
Modelling consumer perceptions of green products, purchasing behaviour and loyalty
}

\author{
Felix Chikosha *(D), Nobubele Potwana ** \\ * Faculty of Commerce and Law, Zimbabwe Open University, \\ 209 Hay Road, Bindura, Zimbabwe \\ chikoshaf@zou.ac.zw \\ ** Faculty of Management Sciences, Durban University of Technology, \\ 41/43 M L Sultan Road, Greyville, Durban 4001, \\ South Africa
}

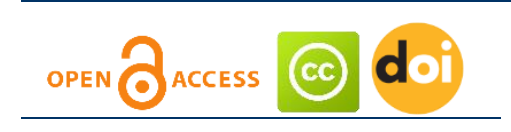

Article history:

Received: May 12, 2021

1st Revision: October 11,

2021

Accepted: November 25, 2021

\section{JEL classification: \\ Q01 \\ Q56}

DOI:

10.14254/jems.2021.6-2.8

\begin{abstract}
Green products have gained prominence on the market largely due to their perceived benefits of environmental sustainability. In view of the growth in influence of green products, the objectives of the study were to determine the impact of product quality on purchase intention for green products; to determine the impact of product quality on purchase intention of green products; to ascertain the influence of environmental concerns on purchase intention for green products; to establish the influence of situations affecting green product purchase on purchase intentions for green products; to establish the impact of preference for green products on purchase intention and to assess the impact of purchase intention on re-purchase intention of green products. To establish these facts the study adopted a quantitative methodology, which made use of a self-reporting questionnaire that was administered to consumer households in parts of Zimbabwe as the target population. The 497 responses received were accepted as the sample size of this study. Data collected was captured and analysed on SPSS (v22.0) and AMOS (v24.0) to yield descriptive and inferential statistics. Structural Equation Modelling was then used to provide estimates of the strength of all the hypothesised relationships. The key findings of the study were that green purchase intention was significantly and positively influenced by product quality, environmental concern, preference for green products, environmental responsibility and selection attributes, but not by situations affecting purchase
\end{abstract}

Corresponding author: Felix Chikosha

E-mail: chikoshaf@zou.ac.zw

This open access article is distributed under a Creative Commons Attribution (CC-BY) 4.0 license. 
behaviour. It was also found that purchase intention had a strong correlation with re-purchase intention. We thus propose that marketers need to formulate and implement green marketing strategies to improve consumer perceptions of green products. We also suggest that marketers should drop deceptive marketing practices that cause consumers to be skeptical about green products.

Keywords: product quality, purchase intention, environmental concerns, green product, re-purchase intention, sustainability.

\section{Introduction}

Green products are products that are environmentally safe and whose production processes are considered to be environmentally sound. Examples of such products include those with chemical compositions that are environmentally-friendly and suitable to recycle (Alsmadi, 2007:342); food items whose manufacturing process does not involve pesticides or harmful chemicals (Thogersen, 2006:149) and energy-saving home appliances (Young et al., 2010:23; Paul and Rana (2012:413).

Worldwide, there is an increased awareness of the dangers of environmental degradation by consumers and organisations at large. Individuals and entities are putting environmental issues at the forefront when deciding on which products to purchase (McDonald and Oates, 2006). This is largely due to an increase in environmental degradation as a result of pollution, resource wastage and ozone layer depletion, amongst other causes. There is now global consensus that unsustainable consumption patterns result in ecological imbalance and ultimately translate into environmental degradation (Hume, 2010). Gradually, consumers are realising the need to take a lead in environmental preservation, which may be achieved by abandoning non-green conventional products for green products.

Rakhsha and Majidazar (2011) claim that green marketing gained prominence in the late 1980 s as an outcome of increased environmental concern and the advent of green consumerism. Historically, green products originated from the United States of America during the 1980s, with consumers demonstrating interest in aspects such as products that are healthy for consumers, carbon free, recyclable and energy efficient (Elliott, 2013:296). Ko, Hwang and Kim (2013) propound that the increased usage of green products is at the epicenter of the trend towards sustainable consumption by consumers. Consumers are now more worried about the environmental impact of their purchase decisions even though Zhu, Li Geng and Qi (2013:2008) have observed that not much is known about green products, despite the greater need to increase their consumption. Furthermore, Chang (2011:20) posits that consumers typically perceive green products as being more expensive and/or of lower grade relative to conventional products. Consumers are unwilling to compromise on aspects such as price, quality, value and performance just for the sake of buying green products.

The growing interest of consumers in environmental protection has compelled many companies to actively involve themselves in making their products greener. The proliferation of environmentally-friendly products has been aided by a thrust on the part of marketers to promote environmentally-friendly products better known as 'green marketing'. The consumer's desire for environmentally-friendly products gave a cue to marketers to start emphasising greenness in their market offerings. At the epicenter of green products promotion are typical terms like energy saving products, healthy foods, recyclable/re-usable packages and carbon-free products.

Whilst there is this global move to green products, this a largely new phenomenon to developing countries. For example in Zimbabwe, noticeable green products are energy saving bulbs, computers, refillable/ reusable consumer product packages, solar energy systems, ethanol blended fuel and washing machines, amongst others. To hasten the growth of a green economy, the government has weighed in by crafting an environmental policy aimed at integrating environmental aspects into national development plans, embarking on specific actions that encourage the consumption of green products. Genetically modified foodstuffs have also been banned and this has been augmented with an increased promotion of organic foods. One example of this was the banning of leaded fuel in favour of E10, a green fuel with large components of ethanol.

Extant literature on green products has concentrated on studying singular concepts like consumer perceptions, purchasing behaviour or consumer loyalty, with not much effort on finding the relationship between such behaviours. Noted studies that have attempted to link the variables 
include consumer attitude and perception towards green products (Yusuf and Fatima, 2015:141); green product quality, green customer satisfaction and green customer loyalty (Asgharian, Salehi, Saleki, Hojabri, Nikkheslat, 2012) and customer environmental satisfaction and loyalty in the consumption of green products (Suki, 2015).There are no known studies that link green product consumer perceptions, purchasing behaviour and loyalty.

Whilst a lot is known about consumer perceptions, purchasing behaviour and consumer loyalty, not much is known about the relationship between the three constructs. This study sought to establish the relationship between these, particularly with regard to green products. In addition, many studies on green products have been done in developed countries, with not much in developing nations. Save for South Africa, there are scant studies on green products conducted in most parts of Africa. This study has shed light on consumer perception of green products, purchasing behaviour and loyalty in the Zimbabwean context.

The objective of this paper therefore is to develop a model that seeks to establish a relationship between consumer perception of green products, purchasing behaviour and loyalty. Specifically, it seeks to establish if favorable consumer perceptions of green products lead to actual purchasing behaviour and more so, increase loyalty to the same products and whether product quality, environmental concern, preference and prevailing situations impact on purchase intention and repurchase intention or loyalty. We thus seek to test the simultaneous effect of these multivariate relationships.

\section{Conceptual framework}

\section{Perception}

Fundamental to the understanding of consumer perception is a determination of the factors influencing perception. Angasa and Kinoti (2013:108) contend consumer perceptions of price, value and quality are considered pivotal determinants of shopping behaviours and product choice. A number of authors who agree with them, cite the following factors to have significant influence on consumer perceptions: perceived price (Schiffman et al., 2010:193; Koller, Floh and Zauner, 2011:1157; Aertsens, Mondelaers, Verbeke, Buysse and Huylenbroeck, 2011:399 and Chang, 2011:20); perceived quality (Schiffman et al., 2010:195; Chang, 2011:20; Ottman, 2011:110; Chen \& Chang, 2012:25); and perceived value (McDougal and Levesque, 2000:394; Aulia, 2016).

A consumer's perception of price and how these perceptions influence their purchase decision affect their rating of products. The price of a product is an important factor in product choice (Schiffman et al, 2010:193). In trying to understand consumer preferences for products one needs to understand the degree of satisfaction or value that a consumer acquires when purchasing a product. Perceived price reflects the value the consumer receives from the purchase. When it comes to green products, Koller, Floh and Zauner (2011:1157) refer to it as "perceived ecological value", which refers to the deliberate effort by consumers who seek products that enhance satisfaction and maximise environmental benefits. The product becomes worthy to consumers if it satisfies needs whilst causing minimal damage to the environment even though there is a dominant perception amongst consumers that green products are overpriced relative to their conventional substitutes (Aertsens, Mondelaers, Verbeke, Buysse \& Huylenbroeck, 2011:399). Chang (2011:20) confirms this stating that the high price of green products is largely due to the high production costs involved.

Consumers also take into account product quality when deciding on which product to purchase. Product quality reflects the perceived quality of a product that is based on a variety of information cues associated with the product. Green products are assessed on how consumers expect them to perform (Schiffman et al., 2010:195). Consistent with this view, Zhuang et al. (2010:1) note that quality plays an important role in enhancing purchase intentions by reducing product performance risk and fostering consumer brand loyalty. Whether green products ought to be of superior quality to ensure greater functional value to consumers is the essence of this paper.

Chang (2011:28) has observed that negative perceptions of the quality of green products create ambivalence towards green products. There is a view that with regard to product quality, these are somewhat inferior and under-perform when compared to conventional products, resulting in consumers being reluctant to compromise on product quality simply for the "sake of saving the earth" and, for the most part, expect environmental products to be environmentally safe without the need for sacrificing quality. While consumers cherish green products for their environmental benefits, inferior quality creates a disservice to these high priced products. Ali et al., (2011:219) place importance on the issue of quality, stating that the environmental quality of green products must be enhanced and clearly conveyed to the consumer in order to gain recognition within the market. 
Consumers are clearly not willing to sacrifice hard earned money on premium priced products (Van Doorn and Verhoef (2011:167). In light of the above, we thus hypothesise that:

\section{H1: Product quality positively impacts on the purchase intention of green products.}

\section{Purchasing behaviour}

Purchasing behaviour has been explained through a number of theories, but none has done so with the utmost rigour as the theory of Planned Behaviour by Ajzen (2005:118). Central to this theory is the prediction of human behaviour with regard to purchasing behaviour, which according to the author is determined by purchase intention. The intention and behavior of a human being are determined by three factors; attitudes towards behavior, subjective norms and perceived behavioral control.

Green purchase behaviour, according to Lee (2009:87), refers to the consumption of products that align with the consumer's environmental concern and are beneficial for the environment. Similarly, Steg and Vlek (2009:309) state that green purchase behaviour involves purchase decisions that result in customer satisfaction with minimum harm to the environment. Agreeing with this position, Datta (2011:128) describes green purchase behaviour as a positive disposition by consumers towards behavioral actions that enhance the welfare of the natural environment. Contributing to this discourse, Han et al. (2010:327) explain that consumers are changing their buying behaviours to more ecologically sound ways by purchasing products that are recyclable, biodegradable and environmentally friendly. The bulk of green products conform to these requirements. Complimentary findings are also presented by Kumar et al. (2011:62.3), who found out consumers are taking action against the omnipresent ecological threat by envisioning environmental issues when they shop. Thus, consumers are actually taking their time to select green products from the maze of available products.

Customers who make these decisions are those who are environmentally conscious. They place importance on the value of the perceived benefits to be derived from the product. They will thus have strong intentions to purchase green products since they draw some measure of satisfaction from using products that do not harm the environment. They have a positive evaluation for green products and so they are likely to purchase green products. This evaluation can be influenced by a person's significant others such as family, friends and peers. This is what Ajzen refers to as subjective norms that are a salient factor underlying environmental behaviours (Fielding et al, 2018; Cheah \& Phau, 2011; Greaves, 2013).

From an environmental protection standpoint, Niaura (2013:75) asserts that a subjective norm is the conscious decision of whether or not to implement pro-environmental behaviour. Thus, in the debacle of whether to go green or not, consumers will look at what society approves with regard to environmental issues. This is in sync with the findings of Kim et al. (2013:260), who concluded that subjective norms are the best predictor of behavioural intentions when selecting an eco-friendly restaurant. This may also be the case with other categories of green products.

Perceived behavioural control is the extent to which consumers control their purchase decisions. Wahid et al. (2011:40) reports that when consumers perceive that their actions have the potential to make a noticeable difference, they are more likely to engage in pro-environmental behaviour. Perceived behavioural control shows how an individual perceives his or her ability to implement such behaviour. Two dimensions of perceived behavioural control have been put forth, namely perceived effectiveness of environmental behaviour and perceived seriousness of environmental problems (Abdul-Muhmin, 2007:237; Jansson et al, 2010:360; and Chea \& Phau, 2011:455).

Perceived effectiveness of environmental behaviour is a component of perceived behavioral control that refers to the capacity of a person to ensure a better environment. For example, if an individual is in a position to preserve the environment, he/she will display pro-environmental behaviour (Abdul-Muhmin, 2007:237). Social status, education and income were all found to have significant influence on the willingness to adapt, indicating that co-habitation, higher education and higher income levels were associated with a willingness to adapt to green product offerings (Jansson et al., 2010:360).

Perceived seriousness of environmental problems is the engagement of individuals in proenvironmental behaviour and depends on the magnitude of the environmental problems. If the environmental problems are acute, there is greater likelihood that consumers will go for green products. Complementary findings are also presented by Gadenne et al. (2011:7686), who posit that when consumers understand the implications of their consumption behaviour for the environment, they will engage in pro-environmental behaviours. When they actually plan to act on an intended behaviour, then that is termed environmental intention. It serves as a pre-supposition of favourable 
environmental activities and encompasses the likelihood of purchasing a particular product as a result of environmental needs (Chen \& Chang, 2012:20). Consistent with this view, Ali and Amad (2012:88) state that green purchase intention is the probability and willingness of a consumer to prefer green products relative to conventional products. Rehman and Dost (2013:102) also note that an increase in the intention to purchase a green product is expected to enhance the propensity of consumers to engage in actual green product purchase. Through their activities, green product marketers should look for ways of enhancing consumer purchase intentions. On this basis, we offer the following hypotheses: products;

H2: Environmental concern positively influences the purchase intention of green

H3: Situations affecting green product purchase positively influence the purchase intention of green products and products.

H4: Preference of green products positively influences the purchase intention of green

\section{Customer loyalty}

Consumer or customer loyalty has been a subject of scholarly enquiry for some time, with scholars coming up with different meanings to the subject. For example, Dowling et al. (2003:296) present a three dimensional model of loyalty, where Model 1 is the attitudinal dimension, referring to loyalty as an attitude that sometimes leads to a relationship with the brand. Model 2 is the behavioural approach that expresses loyalty in terms of revealed behaviour that is a pattern of past purchases. Model 3 conceptualizes loyalty as the contingency approach, where buying is moderated by the individual's characteristics, circumstances and/or purchase situations. Peppers and Rogers (2004:56) as well as Lichtlé and Plichon (2008:121) concur with attitudinal and behavioral loyalty. Lichtlé and Plichon (2008:121) add a third approach which they call the mixed/composite approach.

In this paper we adopt Dowling et al's model because it has been relied upon in studies which include an examination of moderator effects in the four-stage loyalty model of Evanschitzky and Wunderlich, (2006:330); lasting customer loyalty: a total customer experience approach by Mascarenhas, Kesavan and Bernacchi (2006:397); dissecting attitudinal loyalty influences on behavioral loyalty (Bandyopadhyay \& Martell, 2007:35); and the royalty of loyalty: customer relations management, quality and retention (Zineldin, 2006:430).

As an attitude, loyalty is an on-going relationship to a brand, often conditioned on positive customer preferences towards the brand, and is strongly influenced by significant others. It is also defined as a deeply held commitment to re-buy a product consistently in future, despite situational influences (Oliver, 2007:392). By explaining it as "deeply held commitment", the author highlights the attitudinal dimension of loyalty that pinpoints repetitive behaviour. There is some inferred emotional attachment to a product by the customer, which in essence is a favourable attitude towards the product. From an environmental standpoint, green customer loyalty is the customer's desire to a relationship with an institute which has environmental concerns, and to re-buy its products regularly in the future (Chang \& Fong, 2010:2837).

To the extent that customer loyalty is behaviour means it is an outcome of a customer's preference for a particular brand from a selection of similar brands over a period of time, which is the result of an evaluative decision-making process. It is thus built on positive experience and value, which leads to buying products even when that may not appear to be the most rational decision. It is revealed purchase and usage behaviour, often conditioned on customer satisfaction, and is measured by historical purchase of one's brand and competing brands.

Situational loyalty is a contingent relationship to the brand that is often determined by the shopping and purchasing situation. An example of this is when a customer says he/she will buy because the product is always available. That is weak loyalty or promiscuous behaviour. We thus submit that:

H5: Purchase intention of green products positively impacts on the re-purchase intention of green products.

The above hypotheses are depicted in the following hypothesised model below. 
Figure 1: The hypothesised model

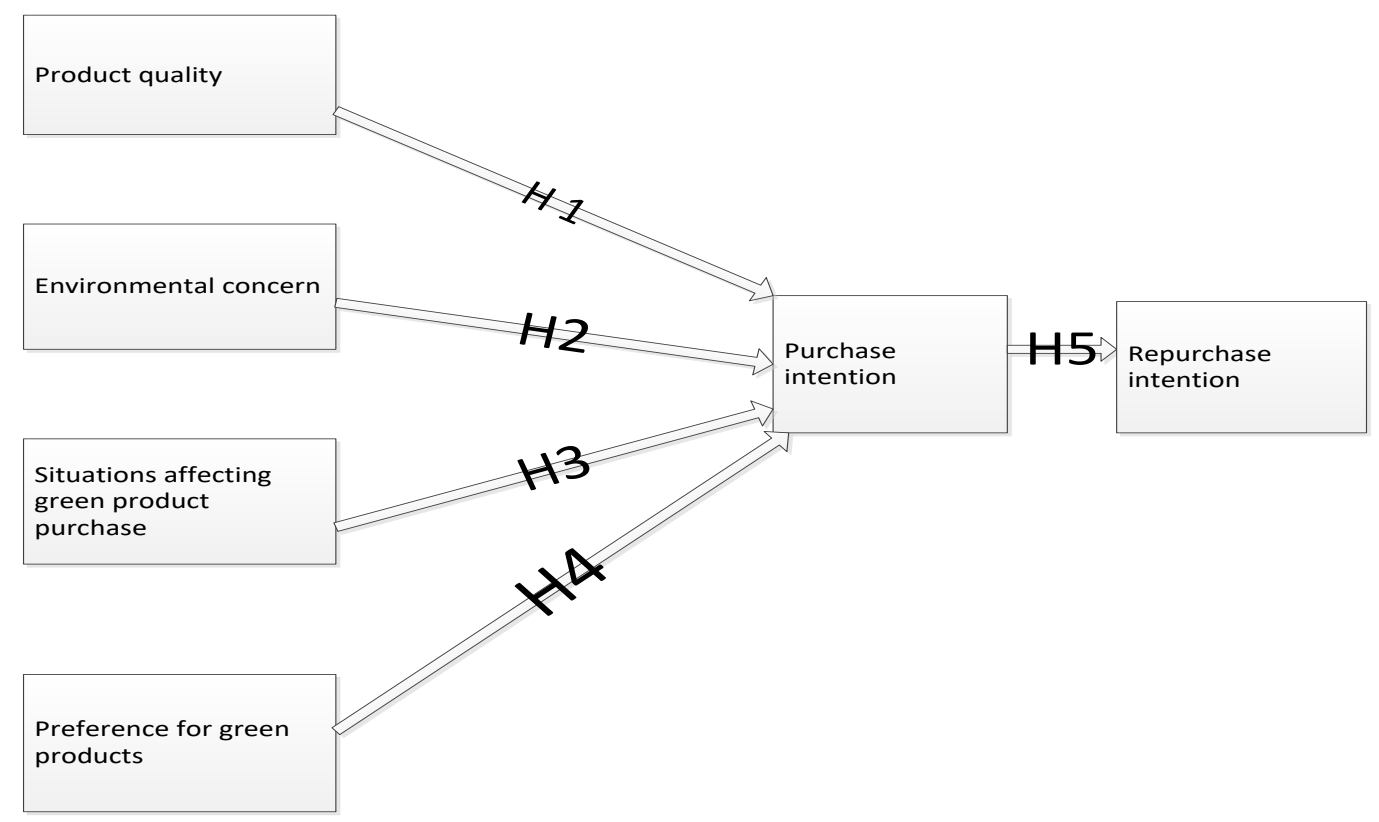

\section{Methods}

\section{Sample and data acquisition}

We used the descriptive research design because the aim was to describe phenomena, such as market characteristics. For sampling purposes, we targeted individual households in four towns of Zimbabwe, namely, Bindura, Marondera, Chinhoyi and Gweru. To select participants, stratified random sampling was employed by firstly, dividing the residential areas into three strata, namely locations, suburbs and the city center. Within these strata, simple random sampling was employed to select households that were included in the survey. To gather data, a structured, self-administered questionnaire was used.

A total of 497 responses were received and this was deemed a sufficient response seeing that the rule of thumb for meaningful Structural Equation Modeling is that at least 300 must be used as a sample size. To prepare for SEM the data was captured on SPSS (v22) and AMOS (V2).The suitability of the measurement model was assessed by conducting confirmatory factor analysis (CFA) comprising all latent and manifest variables, which are product quality, environmental concern, preference for green products, purchase intention, situations affecting purchase of green products and re-purchase intention. Then the structural model, which captured the relationships among the latent variables, was assessed by means of AMOS version 22.0, employing the maximum likelihood estimates. To complement the results of path modelling, Pearson product moment coefficient measure was employed to establish the relationship among the latent variables.

\section{Measures}

With the backing of literature, perception was measured by product quality and purchase intention. Purchase behaviour was measured by environmental concern, repurchase intention and preference.

Product quality is conceptualised by Schiffman et al (200:195) as perceived quality of a product that is based on a variety of information cues associated with the product. Green products are assessed on how consumers expect them to perform. Whether green products ought to be of superior quality to ensure greater functional value to consumers is the essence of this paper. Smith and Paladino (2010:97) posit that the higher the natural content, the higher are perceptions of quality held by consumers. Organic products are favoured by environmentally inclined consumers but they can despise the products for inferior quality. Consumers are not prepared to sacrifice quality for environmental safety (Chang, 2011; Ottman, 2011).

A five-point scale ranging from ' 1 ' strongly agree to ' 5 ' strongly disagree was used to measure three items developed for this paper: (1) green products are reliable; (2) green products are durable; (3) green products reduce wastage. 
Perceived quality, according to Zhuang et al, (2010:1) plays an important role in enhancing purchase intention by reducing product performance risk and fostering consumer brand loyalty. Additional factors such as perceptions of price, perceived value and subjective norms are considered pivotal determinants of shopping behaviours and product choice that influence perception. Kim et al (2013: 260) emphasises that subjective norms are the best predictor of intentions.

A five-point scale ranging from ' 1 ' strongly agree to ' 5 ' strongly disagree was used to measure three items developed for this paper: (1) I have been buying green products over the last three months; (2) I am going to purchase green products more; (3) I will recommend green products to my friends and family.

Environmental concern refers to the emotional attachment of an individual to the welfare of the environment. It explains the preference for bio-degradable or recyclable products by environmentally inclined consumers (Yeung, 2004:101). From the above insinuation, it might be agreeable that consumers who exhibit high levels of environmental concern are presumed to develop favourable purchase intentions towards green products (Kim and Choi 2005:596). Thus, a proenvironment consumer will favour bio-degradable products over their opposite numbers. Certain factors such as environmental attitude (Lee, 2008:578; Samarasinghe, 2012:91); product quality (Chang, 2011:28; Ali et al. 2011:219; Chen \& Chang, 2012:4) and environmental knowledge (Chea and Phau, 2011:456) do bear a major influence on environmental concern.

To the extent that environmental concern is an attitude, Lee (2008) Tantawi, O'Shaughnessy, Gad and Ragheb (2009:36) agree with Yeung (2004), stating that environmental concern is an attitude that reflects the level of consumer apprehension of the well-being of the environment. The attitudes will be aptly expressed in the products they purchase. Consistent with this view, Lu et al., (2013:5) highlight that environmental concern drives consumer values and lifestyles towards the consumption of green products. According to Lu et al. (2013), consumers with an environmental inclination will purchase green products which cause minimal harm to the environment.

A five-point scale ranging from ' 1 ' strongly agree to ' 5 ' strongly disagree was used to measure three items developed for this paper: (1) I am environmentally responsible; (2I am knowledgeable on green products; (3) It is important to me that the products I use do not harm the environment.

When a consumer exhibits a deeply held commitment to re-buy a product consistently in future, despite situational influences, this according to Oliver (2007:392), is a repetitive behaviour, which is attitudinal. That inferred emotional attachment to a product by the customer is in essence a favourable attitude towards the product. From an environmental standpoint, the desire to have a relationship with an institute which has environmental concerns, and to re-buy its products regularly in the future is loyalty (Chang \& Fong, 2010:2837).

A five-point scale ranging from ' 1 ' strongly agree to ' 5 ' strongly disagree was used to measure three items developed for this paper: (1) I have used green products before; (2) I was satisfied with most of eco-friendly products I bought; (3 I intend to buy green products in future.

With this favourable attitude towards a product, a consumer starts to develop a pleasure dimension associated with the brand known as affective loyalty (Harris \& Goode 2004:141). These repeated positive interactions with the brand develop a deeper level of commitment where the consumer is committed to repurchase the brand and is usually very well educated about the brand's advantages. The commitment is deeply anchored in the customer's mind and motivates repurchases of the brand's product/service. Harris and Goode (2004) refer to this as conative loyalty.

A five-point scale ranging from ' 1 ' strongly agree to ' 5 ' strongly disagree was used to measure three items developed for this paper: (1) I prefer green products over conventional products; (2) I first look for green products when shopping; (3) I will not buy if green products are not available.

There is also situational loyalty, which suggests that the relationship between attitude and behavior is moderated by the consumer's circumstances, such as budget effects, time pressure or purchase situation, for example product availability and promotions. These factors or situations determine whether the brand is seen as desirable when a need for such product emerges (Dowling et al., 2003:295). In the same vein, Bandyopadhyay and Martell (2007:38) state that brand choice is dictated through situations and leaves little room for variations of attitude in predicting purchasing behaviour. Such situations may include a businesses' stock being out or unavailable. These situational factors therefore reinforce the need for customer loyalty to be separated from repeat purchasing behaviour.

A five-point scale ranging from ' 1 ' strongly agree to ' 5 ' strongly disagree was used to measure three items developed for this paper: 91) I will revise my budget to accommodate green product purchases; (2) I want to change my lifestyle to promote the environment; (3) I spend time and effort in environmental activities such as recycling. 


\section{Results}

Table 1 depicts means, standard deviations and intercorrelations among the variables as well as Cronbach's alpha for the scales used in this paper, which are Situations affecting green purchase (SA); Product Quality (PQ); Purchase Intention (PI); Environmental Concern (EC); Preference of Green Products (PGP) and Repurchase Intention (RI). The Cronbach's alphas are within the benchmark of .7 as suggested by Field (2009:675).

\begin{tabular}{|c|c|c|c|c|c|c|c|c|c|}
\hline Variables & Means & s.d & & 1 & 2 & 3 & 4 & 5 & 6 \\
\hline 1. SA & 3.71 & .92 & .73 & 1.000 & & & & & \\
\hline 2. $P Q$ & 3.93 & 83 & .74 & 0.648 & 1.000 & & & & \\
\hline 3. PI & 3.92 & .83 & .7 & 0.771 & 0.795 & 1.000 & & & \\
\hline 4. EC & 4.08 & .75 & .69 & 0.682 & 0.656 & 0.805 & 1.000 & & \\
\hline 5. PGP & 3.43 & 1.00 & .77 & 0.837 & 0.678 & 0.880 & 0.652 & 1.000 & \\
\hline 6. RI & 3.92 & .82 & .68 & 0.791 & 0.731 & 0.932 & 0.741 & 0.987 & 1.000 \\
\hline
\end{tabular}

This table indicates that there are strong and positive correlations between constructs. For example there is a strong and positive correlation between PI and SA $(\mathrm{r}=0.771 ; p<0.01)$, PI and PQ $(\mathrm{r}=0.795 ; p<0.01)$, PI and EC ( $\mathrm{r}=0.805 ; p<0.01)$, PI and PGP ( $\mathrm{r}=0.880 ; p<0.01)$, and PI and RI ( $\mathrm{r}$ $=0.932 ; p<0.01$ ) respectively. The six constructs in the model measured different aspects of green product perception and subsequent purchasing behaviour, hence a high degree of inter-correlation was expected. The resulting correlation statistics indicate that there is a significant linear relationship between any two constructs in the model. This concludes the confirmation process for the structure of the constructs through the measurement model.

Inter-correlation between constructs was also computed from the measurement model and the result was a pair-wise correlation matrix. The Pearson product moment correlation coefficient measure was preferred because the variables and their constructs were assumed to have an underlying continuous distribution.

The results from the reliability analysis show that the Cronbach's alpha coefficient ranges between 0.676 and 0.771 for the six constructs, suggesting that there is internal consistency in each construct. The reliability of the scales was therefore deemed adequate and all the constructs were reliable. We used structural equation methodology to test the hypothesised model illustrated in Figure 1 above.

\section{Measurement Model}

To prevent spurious results, the SEM process was based on the assumptions that the data was normal, with no outliers; that the variables and constructs should meet a certain minimum level of reliability and validity above the requirement that they should be positively correlated and that before interpretation of results, the measurement model together with the structural model should meet certain ranges of values for respective measures of fit indices. The use of many varied fit indices aided in averting possible pitfalls in specification and procedures. Gross deviations from SEM assumptions are understood to pose serious problems as they may lead to biased estimates of regression weights in the final model.

As per the assumptions of the structural modelling equation, survey data was screened for normality and outliers before anything was done. Outliers were spotted using the Mahalanobis distance. Three observations that were farthest from the centroid were spotted and they indicated the typical nature of the responses and thus were labelled as outliers. The three cases in the questionnaire were subsequently deleted for their high distance from the centroid. Concerning the normality of variables, Field (2013:172) points out that for a large sample size like the one in this study, the central limit theorem contends that the assumption of normality does not have much bearing on data analysis. Although the central theorem caters for the issue of normality in this study, the skewness and kurtosis of each item in the model were done and the study confidently asserts that the data meets the normality assumption. Having eliminated outliers and demonstrated the normality of the remaining data, the analysis proceeded to run the structural equation model with the data. Running a structural equation model took a two-step approach that included designing, testing, and improving a measurement model and subsequently building the structural model.

The measurement model delineates and stipulates how the observed variables depend on the latent unobserved variables and is used to confirm the structure of each construct. The measurement model was constructed in the IBM package AMOS version 24 and was accessed using confirmatory factor analysis (CFA). Before completing confirmatory factor analysis, measures of sphericity and 
sampling adequacy needed to be computed for the 18 items that are to be used to measure the six constructs and these are depicted in in table 2 below.

\begin{tabular}{lcc} 
Table 2: KMO and Bartlett's test & & \\
\multicolumn{2}{c}{ Kaiser-Meyer-Olkin Measure of Sampling Adequacy } & $\mathbf{0 . 9 2 9}$ \\
\hline Bartlett's Test of Sphericity & Approx. Chi-Square & 3729.004 \\
& Df & 153 \\
& Sig. & 0.000 \\
\hline
\end{tabular}

The results above show a statistically significant Bartlett's Test of Sphericity with approximate chi-square of 3729.004 ( $p$-value=0.000). Both measures confirm the appropriateness of the data and hence the analysis to reduce the number of items, and identify the dimensions of latent variables could be done. The proposed model was turned into an initial measurement model. From the initial measurement model, the CFA results displayed marginally acceptable fit indices but not great enough for further analysis. A close diagnosis of factor loadings, modification indices and the standardised residual covariance matrix retrieved from AMOS output showed that items GP3, PI1, RI3 and EC2 had to be deleted from the measurement model, which was done in line with the advice of Hair et al, (2014).

According to Ford et al. (1986), deleting items with poor factor loadings aid in reducing the measurement error and increasing reliability among items, which in turn enhances the model fit. Accordingly, the measurement model was adjusted and an improved model without the deleted items was arrived at. New fit indices were calculated and this resulted in acceptable values enough for further analysis. Table 3 below shows the modified model fit indices.

\begin{tabular}{cccc} 
Table 3: Modified model fit indices & & \\
Fit index & $\begin{array}{c}\text { Acceptable threshold } \\
\text { (Hair et al., 2014) }\end{array}$ & $\begin{array}{c}\text { Modified Model fit index } \\
\text { value }\end{array}$ & Comment \\
\hline$\chi 2 / D F$ & $<3.000$ & 2.759 & Acceptable \\
GFI & $\geq 0.800$ & 0.954 & Satisfactory \\
RMSEA & $\leq 0.080$ & 0.060 & Acceptable \\
IFI & $\geq 0.900$ & 0.943 & Acceptable \\
CFI & $\geq 0.900$ & 0.963 & Acceptable \\
TLI & $\geq 0.900$ & 0.945 & Acceptable \\
\hline
\end{tabular}

After accepting the measurement model fit indices the study proceeds to show the final measurement model. Figure 2 below presents the final measurement model.

Figure 2: Measurement model

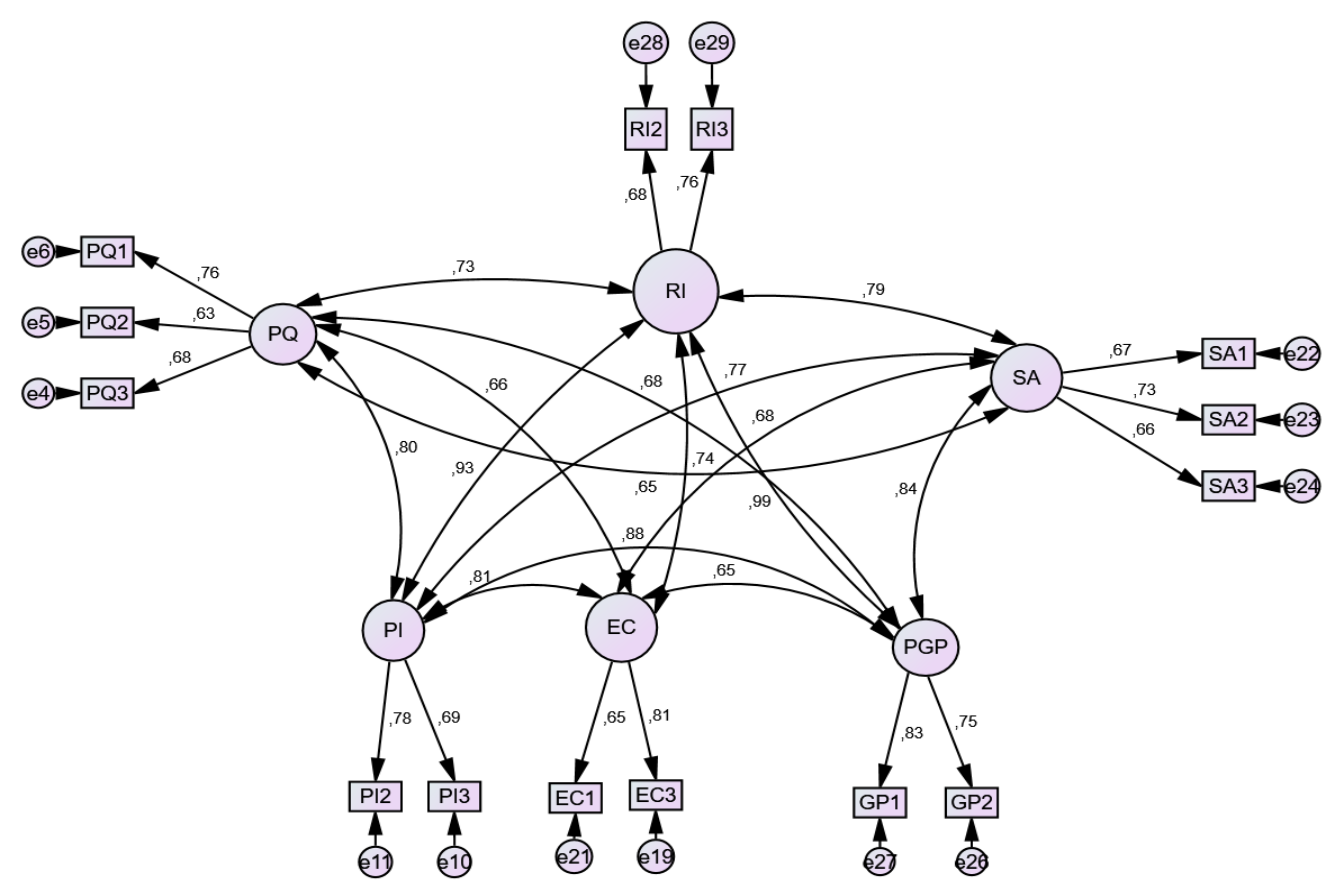


The next step was to test the hypotheses through a structural model, which was subjected to model fit indices, the results of which are shown below.

\begin{tabular}{cccc} 
Table 4: Structural model fit indices & & \\
Fit index & $\begin{array}{c}\text { Acceptable threshold } \\
\text { (Hair et al., 2014) }\end{array}$ & $\begin{array}{c}\text { Modified Model fit index } \\
\text { value }\end{array}$ & Comment \\
\hline$\chi 2 / D F$ & $<3.000$ & 2.875 & Acceptable \\
GFI & $\geq 0.800$ & 0.949 & Acceptable \\
RMSEA & $\leq 0.080$ & 0.061 & Acceptable \\
IFI & $\geq 0.900$ & 0.937 & Acceptable \\
CFI & $\geq 0.900$ & 0.958 & Acceptable \\
TLI & $\geq 0.900$ & 0.942 & Acceptable \\
\hline
\end{tabular}

The structural model had a good fit as informed by the acceptable thresholds (Hair et al, 2014). This set the way for full hypothesis testing and interpretation of the model. The figure below presents the resulting structural model of the present study retrieved from AMOS version 21 .

Figure 3: Structural equation model path diagram

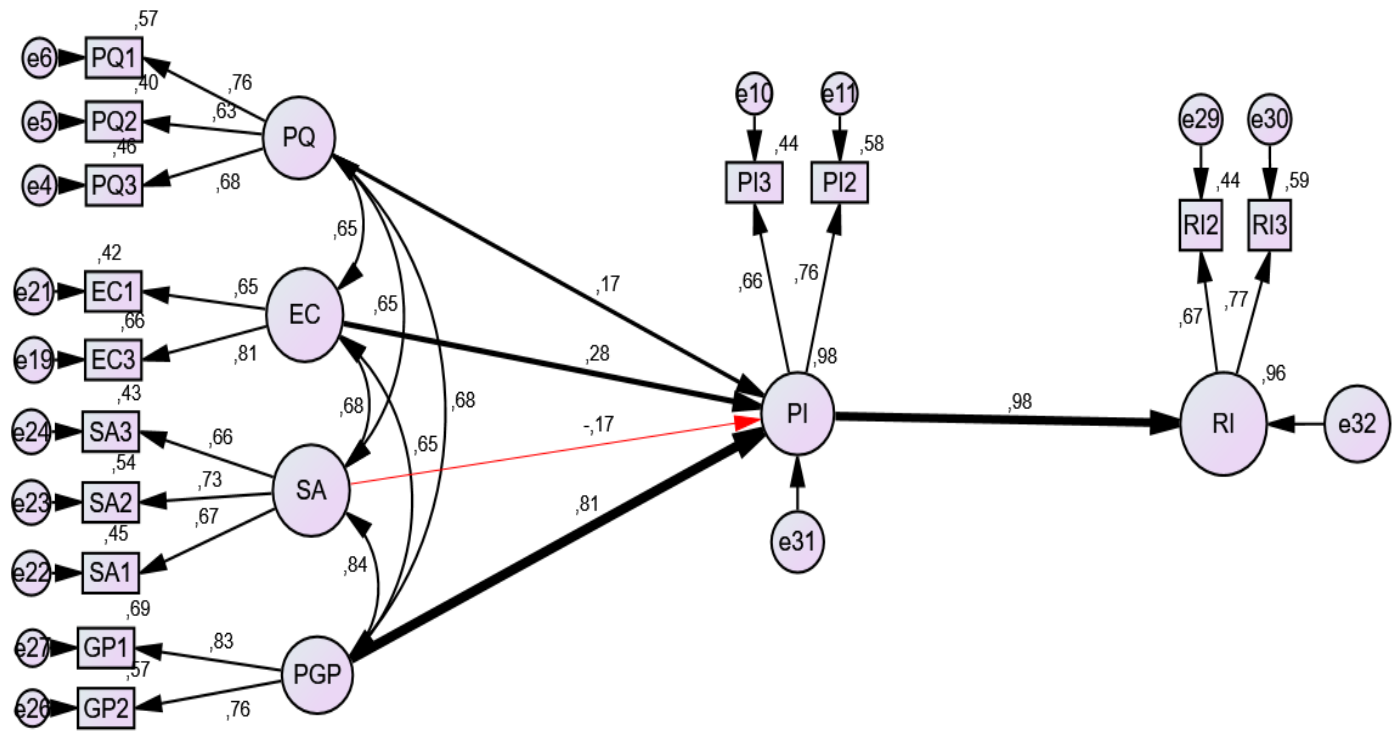

In the above structural model path diagram, unidirectional arrows represent causal relationship between a variables and its direction. The bidirectional arrows represent a correlational relationship between variables without a clearly defined causal direction. Circles and ovals represent latent variables, while squares or rectangles signify measured variables. Residuals to each variable are always unobserved and so are denoted by small ovals or circles. It is instructive to also highlight that all constructs were not measured directly and are thus latent variables in the model.

From the path diagram, it is immediately evident that PI is predicted by PGP, SA, EC and PQ. However, only PGP, EC and PQ have a statistically significant causal impact on PI. This is made even more apparent in Table 5 which summarises the results of the structural model and also shows statistical significance. From the path diagram, PI can in turn predict RI. The model is able to explain a large percentage of the variance of PI as shown by a high squared multiple correlations $\left(\mathrm{R}^{2}=98 \%\right)$ and $96 \%$ for RI.

\begin{tabular}{cccccccc}
\multicolumn{6}{l}{ Table 5: Paths relationships among constructs and confirmation of hypotheses } \\
\hline IV & & \multirow{2}{*}{ DV } & $\begin{array}{c}\text { Standardised } \\
\text { Estimates ( } \beta \text { values) }\end{array}$ & p values & S.E. & $\begin{array}{c}\text { Decision on } \\
\text { Hypotheses }\end{array}$ & $\begin{array}{c}\text { Variance } \\
\text { Explained }\end{array}$ \\
\hline PQ & $--->$ & & 0.168 & 0.014 & 0.056 & Accepted & \\
EC & $--->$ & PI & 0.279 & 0.001 & 0.053 & Accepted & 0.983 \\
SA & $--->$ & & -0.175 & 0.148 & 0.086 & Rejected & \\
PGP & $--->$ & & 0.806 & 0.001 & 0.082 & Accepted & \multirow{2}{*}{ PI } \\
PI & $--->$ & RI & 0.981 & 0.001 & 0.088 & Accepted & 0.962 \\
\hline
\end{tabular}

Notes: IV= Independent variables; DV= Dependent variables; SE: Standard Error 
Standardised estimates represent the strength of the predictive influence of the IV on the DV. It is apparent that PGP is the strongest predictor of PI $(\beta=0.806 ; p$-value $=0.001)$. This shows that preference for green products may be the leading predictor of purchase intentions. This result may be explained by the fact that a high preference for green products predisposes an individual to exhibit high purchase intentions for the products and may further influence family and friends. The figure below depicts the revised model which confirms the hypotheses:

\section{Figure 4: Revised model - consumer perception of green products, purchase behaviour and} loyalty

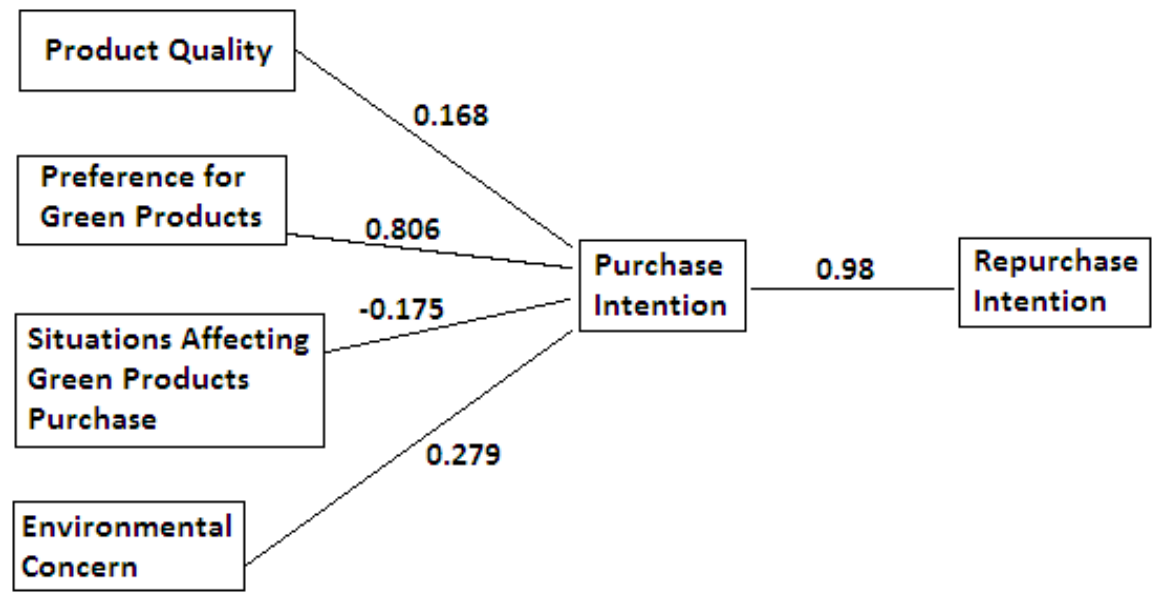

The structural model also materialised (double headed-arrows) correlations between the predictors of PI as shown below.

Table 6: Correlations materialised in the model

\begin{tabular}{cccc} 
& Correlations & & Pearson correlation coefficient \\
\hline PQ & $<->$ & EC & 0,655 \\
PQ & $<-->$ & SA & 0,649 \\
PQ & $<-->$ & PGP & 0,679 \\
EC & $<-->$ & SA & 0,68 \\
EC & $<-->$ & PGP & 0,651 \\
SA & $<-->$ & PGP & 0,838 \\
\hline
\end{tabular}

All correlations are significant at the 0.001 level

The Pearson product moment correlation coefficients show strong, positive and statistically significant correlations between predictors of PI. This is exemplified by $\mathrm{PQ}$ which is strongly correlated to EC ( $\mathrm{r}=0.655 ; p<0.001)$, SA $(\mathrm{r}=0.649 ; p<0.001)$ and PGP $(\mathrm{r}=0.679 ; p<0.001)$. There is also a noticeable strong correlation between SA and PGP $(\mathrm{r}=0.838 ; p<0.001)$. These results meet the assumptions of structural equation modelling that the independent variables should be reasonably correlated in order for the model to generate a sensible set of results, thereby reinforcing the acceptability of the model.

\section{Discussion and conclusion}

The overarching aim of the study was to establish the extent to which product quality, environmental concern, preference and prevailing situations impact purchase intention and repurchase intention or loyalty by testing a model that links these constructs together. The results of the test performed have been dealt with above. The strong links between product quality and intention to purchase green products and how environmental concern is a strong predictor of purchase intention have strong implications for government, green marketers and consumers as they all find themselves, one way or the other, enmeshed in environmental issues. They are all affected by the scourge of climate change and environmental degradation. Escalating environmental problems partly due to business and consumer consumption activities are enough evidence to steer the government, business and consumers to engage in pro-environmental behaviours, some of which are advised below.

Government must actively engage in providing information on environmental problems. Objective environmental knowledge is considered a strong contributor to the formation of consumer 
attitudes towards green products. Through the responsible environment ministry, central government can make efforts to provide consumers with pertinent information on environmental problems.

Since environmental concern has been found to be a significant factor in the formation of purchase intention, it is pertinent that government conducts environmental awareness campaigns to educate consumers on the importance of preserving the environment. Individual consumers should feel it is their responsibility to maintain a healthy environment. Consumers who exhibit high levels of environmental concern are presumed to develop favourable purchase intentions towards green products (Kim \& Choi, 2005:596).

Sometimes moral persuasion to encourage pro-environmental behaviour may fall on deaf ears. Central government and local authorities must put in place measures to ensure that businesses consumers behave in an environmentally friendly way. For example, the Zimbabwean government outlawed the use of infra-red bulbs in favour of energy saving bulbs. Retailers are also no longer allowed to sell thin plastic bags which are not reusable.

The government should move further to impose stiff penalties on businesses and consumers who engage in unsustainable environmental practices. Government may also introduce tax exemptions and subsidies for organisations that operate in an environmentally sustainable way. This will see a lot of organisations turn to the production of green products.

In this paper, preference for green products was found to have the most profound influence on green purchase intentions. Factual content on green products has to be the mainstay of green product advertisements to make sure consumers develop a liking for green products. Consumers should always associate green products with environmental preservation whenever they think if these products.

The study results illustrated that product quality has a direct impact on purchase intention. Quality plays a key role in enhancing purchase intentions by reducing product performance risk and fostering consumer brand loyalty. This suggests that in terms of performance, green products must always perform better than conventional products. Green products should give consumers value for money.

As preference for green products emerged as the outstanding predictor of purchase intention, green marketers should avoid green washing tendencies. Green washing, which essentially is deceptive marketing, creates negative feelings for green products. Green product marketers must avoid making unfound claims about their products. Instead, they should focus on promoting the real strengths of their products to enhance their credibility. They must focus on consumer value positioning, calibration of consumer environmental knowledge and the credibility of green product claims.

Besides producing green products, business may have to turn to green marketing strategies that may include green advertising and eco-labelling to sensitize consumers on environmental matters. Green advertising is considered as the most common tool for conveying environmental messages to the public (Leonidou et al., 2011:6).

Re-purchase intention signifies a satisfied consumer who is likely to stay loyal to a product offering. There should be ways to increase repeat purchase of green products. Green product businesses should devise place consumer loyalty programs to ensure increased patronage. Such programs may include perennial sales promotions to induce trial and repeated purchase of green products; and giving awards to individuals and institutions for significant purchase of green products.

Once consumers understand their contribution to environmental problems, they will more actively increase their green product purchases. Consumers will also actively participate in recycling activities.

Social networking media is being used to make pro-environmental behaviour trendy by green consumers. This is may have a snowball effect on the wider population in Zimbabwe and the world over.

Consumers must really take severe action to preserve the environment as continued environmental degradation seriously affects their health and quality of life. Worsening of environmental problems not only will affect the healthiness of Zimbabweans, but also will negatively impact future generations.

By developing a model of factors that influence purchase intention leading to re-purchase intention, the model becomes an important tool for predicting consumer perception of green products, purchasing behaviour and loyalty in the Zimbabwean scenario. The model may be generalised to predict consumer perceptions of green products, purchasing behaviour and loyalty in other countries and it can be used by green product marketers to craft better marketing strategies for green products. Future research could then be conducted in bigger and more affluent suburbs such as Harare and Bulawayo, to see how the results pan out. Other data collection techniques such 
as observation or interviews could be used and perhaps use a larger sample size to increase the statistical power of the findings. Additionally, although the scales to measure the constructs have been found to have high internal consistency, it would be valuable to improve the validity of the scales by replicating the study.

\section{Aknowlegment}

The authors thank the anonymous reviewers for their insightful comments on this paper.

\section{Funding}

The author(s) received no financial support for the research, authorship, and/or publication of this article.

\section{Declaration of conflicting interests}

The author(s) declared no potential conflicts of interest with respect to the research, authorship, and/or publication of this article.

\section{Citation information}

Chikosha, F., \& Potwana, N. (2021). Modelling consumer perceptions of green products, purchasing behaviour and loyalty. Economics, Management and Sustainability, 6(2), 102-118. doi:10.14254/jems.2021.6-2.8.

\section{Reference}

Abdul-Muhmin, A.G. (2007). Explaining consumers' willingness to be environmentally friendly. International Journal of Consumer Studies, 31(3), 237-247.

Aertsens, J., Verbeke, W., Mondelaers, K., \& Huylenbroeck, G.V. (2011). Personal determinants of organic food consumption, A review. British Food Journal, 111(10), 399

Ajzen, I. (2005). Attitudes, Personality and Behaviour .2 $2^{\text {nd }}$ ed. Open University Press, McGraw-Hill Education, 118

Al-Debei, M.M., Al-Lozi, E., \& Papazafeiropoulou, A. (2013). Why people keep coming back to Facebook, explaining and predicting continuance participation from an extended theory of planned behaviour perspective. Decision Support Systems, 55(1), 43-54.

Ali, A., Khan, A. A., and Ahmed, I. (2011). Determinants of Pakistani consumers' green purchasing behaviour, Some insight from a developing country. International Journal of Business and Social Science, 2(3), 217-226.

Alsmadi, S. (2007). Green marketing and the concern over the environment, measuring environmental consciousness of Jordanian consumers. Journal of Promotion Management, 13(3), 339-361.

Angasa, P and Kinoti, M. W. (2013). Factors Affecting Consumer Perception Of Kenyan Manufactured Fast Moving Consumer Goods In The East African Community. A Case of Laundry Detergents Products. DBA Africa Management Review, 3 (2), 108-123.

Arantola, H. (2001). Uskollinen asiakas - Kuluttaja asiakkuuksien johtaminen. Porvoo, 26-27

Arslan, T., Yilmaz, V., \& Aksoy, H. K. (2012). Structural equation model for environmentally conscious purchasing behaviour. International Journal of Environmental Research, 6(1), 323-334.

Asgharian, R., Salehi, M., Saleki, Z.S., Hojabri, R., \& Nikkheslat, M. 2012.Green product quality, green customer satisfaction, and green customer loyalty. International Journal of Research in Management \& Technology, Vol. 2, No. 5, pp.499-503

Atkinson, L., \& Kim, Y. (2014). I drink it anyway and I know I shouldn't, Understanding green consumers' positive evaluations of norm-violating non-green products and misleading green advertising. Environmental Communication, 1, 1-21. 
Aulia, S.A., Sukati, I., \& Sulaiman, Z (2016). A Review, Customer Perceived Value and its Dimension. Asian Journal of Social Sciences and Management Studies, 3(2), 150-162.

Bagozzi, I. R. P., \& YI, Y. (2012). Specification, evaluation and interpretation of structural equation models. Journal of the Academy of Marketing Science, 40, 8-34.

Bagozzi, R.P., \& Yi, Y. (1988). On the evaluation of structural equation models. Journal of the Academy of Marketing Science, Vol. 16 No. 1, pp. 74-94

Chang N and Fong, C (2010). Green product quality, green corporate image, green customer satisfaction, and green customer loyalty. African Journal of Business Management Vol. 4(13), pp. 2836-2844

Chang, C. (2011). Feeling ambivalent about going green, Implications for green advertising processing. Journal of Advertising, 40(4), 19-31.

Cheah, I., \& Phau, I. (2011). Attitudes towards environmentally friendly products, The influence of eco-literacy, interpersonal influence and value orientation. Marketing Intelligence and Planning, 29(5), 452-472.

Chen, T., \& Chai, L. (2010). Attitude towards the environment and green products, perspective. Management Science and Engineering, 4(2), 27-39.

Chen, Y., \& Chang, C. (2012). Enhance green purchase intentions, The roles of green perceived value, green perceived risk and green trust. Management Decision, 50(3), 4-520.

Chin, W.W., Gopal, A., Salisbury, W.D., (1997). Advancing the theory of adaptive structuration, the development of a scale to measure faithfulness of appropriation. Inf. Syst.Res. 8 (4), 342-367.

D’Souza, C., Taghian, M., \& Khosla, R. (2007). Examination of environmental beliefs and its impact on the influence of price, quality and demographic characteristics with respect to green purchase intention. Journal of Targeting, Measurement and Analysis for Marketing, 15(2), 69-78.

Datta, K., \& Ishaswini, I. (2011). Pro-environmental concern influencing green buying, A study on Indian consumers. International Journal of Business and Management, 6(6), 124-133.

Davis, B., Lockwood, A., Pantelidis, I., \& Alcott, P. (2008). Food and beverage management.3rd ed. Oxford. Butterworth-Heinemann, 180

de Chernatony, Leslie, Malcolm, McDonald and Elaine, Wallace. (2011). Creating powerful Brands. $4^{\text {th }}$ Ed. New York, Routledge, 91

Dietz, T, Fitzgerald, A., \& Shwom, R. (2005). Environmental values. Annual Review of Environment and Resources, 30(1), 335-372.

Dowling G. R, Hammond, K and Uncles M. D (2003). Customer loyalty and customer loyalty programs. Journal of Consumer Marketing, 20(4), 294-316.

Elliot, R. (2013). The taste for green, The possibilities and dynamics of status differentiation through green consumption. Poetics, 41, 294-322.

Fielding, K., McDonald, R. Louis, W. R. (2008). Theory of planned behaviour, identity and intentions to engage in environmental activism. Journal of Environmental Psychology 28 (4), 318-326.

Gadenne, D., Sharma, B., Kerr, D., \& Smith, T. (2011). The influence of consumers' environmental beliefs and attitudes on energy saving behaviours. Energy Policy, 39(12), 7684-7694.

Greaves, M., Zibarras, L.D., \& Stride, C. (2013).Using the theory of planned behavior to explore environmental behavioural intentions in the workplace. Journal of Environmental Psychology, 34(1), 109-120.

Gregoire, M.B. (2010). Food service organization, a managerial and system approach.

Gupta, S., \& Ogden, D.T. (2009). To buy or not to buy? A social dilemma perspective on green buying. Journal of Consumer Marketing, 26(6), 376-391.

Hair, J. F., Jr., Hult, G. T. M., Ringle, C. M., and Sarstedt, M. (2014). A Primer on Partial Least Squares Structural Equation Modeling (PLS-SEM). Thousand Oaks, CA, SAGE Publications Ltd.

Hair, J.F., Wolfinbarger, M., Ortinau, D.J., \& Bush, R.P. (2013).3 ${ }^{\text {rd }}$ ed. Essentials of marketing research. New York, McGraw-Hill. 
Han, H, Hsu, L., \& Sheu, C. (2010). Application of the Theory of Planned Behavior to green hotel choice, Testing the effect of environmental friendly activities. Tourism Management, 31(1), 237-334. .

Haytko, L. D., \& Matulich, E. (2008). Green advertising and environmentally responsible consumer behaviours, Linkages examined. Journal of Management and Marketing Research, 1(1), 1-10.

Hume, M. (2010). Compassion without action, Examining the young consumers' consumption and attitude to sustainable consumption. Journal of World Business, 45, 385-394.

Jansson, J., Marell, A., \& Nordlund, A. (2010). Green consumer behaviour, determinants of curtailment and eco-innovation adoption. Journal of Consumer Marketing, 27(4), 358-370.

Kim, Y.J., Njite, D., \& Hancera, M. (2013). Anticipated emotion in consumers' intentions to select ecofriendly restaurants, Augmenting the theory of planned behaviour. International Journal of Hospitality Management, 34(1), 255-262.

Kincaid, J. (2003) Customer relationship management, getting it right, London, Prentice Hall Professional, 10.

Ko, E., Hwang, Y. K., \& Kim, E. Y. (2013). Green marketing' functions in building corporate image in the retail setting. Journal of Business Research, 66, 1709-1715.

Kotler, P., \& Armstrong, G. (2010). Principles of Marketing. 13 ${ }^{\text {th }}$ ed. Pearson Education, New Jersey, 179

Kotler, P., and Armstrong, G., (2014). Principles of Marketing, Global edition. Edinburg, Pearson Education limited.

Kumar, B. (2012). Theory of Planned Behaviour Approach to understand the purchasing behaviour for environmentally Sustainable Products, Working Paper Series. Indian Institute of Management.1, 1-43.

Lee, K. (2009). Gender differences in Hong Kong adolescent consumers' green purchasing behaviour. Journal of Consumer Marketing, 26(2), 87-96.

Lichtlé, M.C., \& Plichon, V., (2008). Understanding better consumer loyalty. Recherché et Applications en Marketing, 23(4), 121.

McDonald, R. P., \& Ho, M. H. R. (2002). Principles and practice in reporting statistical equation analyses. Psychological Methods, 7(1), 64-82.

McDonald, S., \& Oates C. (2006), Sustainability, Consumer perceptions and marketing strategies, Business Strategy and the Environment, 15 (3), 157-170.

McDonald, Seonaidh, Caroline J. Oates, Panayiota J. Alevizou, C.William Young and Kumju Hwang (2012). Individual strategies for sustainable consumption. Journal of Marketing Management. 28(3-4), 445-468.

McDougall H. G., Levesque T. (2000). Customer satisfaction with services, putting perceived value into the equation. Journal of Services Marketing, 14(5), 392-410.

McMullan, R., and Gilmore, A. (2002). The conceptual development of customer loyalty measurement, A proposed scale. Journal of Targeting, Measurement and Analysis for Marketing, 11 (3), 230 243.

Mostafa, M.M. (2007). A hierarchical analysis of the green consciousness of the Egyptian consumer. Psychology and Marketing, 24(5), 445-473.

Niaura, A. (2013).Using the theory of planned behavior to investigate the determinants of environmental behavior among youth. Environmental Research, Engineering and Management, 1(63), 74-81.

Oliver, R. L. (2007). Satisfaction, A Behavioral Perspective on the Consumer, New York, McGraw Hill, 392.

Ottman, A.J. (2011). The new rules of green marketing, Strategies, tools, and inspiration for sustainable branding. Sheffield, United Kingdom, Greenleaf Publishing Limited, 110

Park, J. S., \& Lee, J. (2014). Segmenting green consumers in the United States, Implications for green marketing. Journal of Promotion Management, 20(5), 571-589. 
Paul, J., \& Rana, J. (2012). Consumer behaviour and purchase intention for organic food. Journal of Consumer Marketing, 29(6), 412-422.

Peattie, K. (2001). Golden goose or wild goose? The hunt for the green consumer. Business Strategy and the Environment, 10, 187-199.

Peppers, D., \& Rogers, M. (2004). Managing customer relationships, a strategic framework, New York, John Wiley and Sons, 57

Pirani, E., \& Secondi, L. (2011). "Eco-Friendly Attitudes, What European Citizens Say and What They Do". International Journal of Environment Research, 5, 67-84.

Rahbar, E., \& Wahid, N.A. (2011). Investigation of green marketing tools" effect on consumers" purchase behavior. Journal of Business Strategies Series, 12(2), 73-83.

Rakhsha, R., \& Majidazar, M. (2011). Evaluation of effectiveness of green marketing mix on consumer satisfaction and Loyalty, Case study of the East Azarbaijan Pegah dairy company in Tabriz, Iran. Middle-East Journal of Scientific Research, 10(6), 755-763.

Rehman, Z., \& Dost, M. K. D. (2013). Conceptualizing green purchase intention in emerging markets, An empirical analysis on Pakistan. Paper presented at the West East Institute Academic Conference held in Istanbul 1n 2013.Turkey, 99-

Rezai, G., Teng, P. K., Mohamed, Z., \& Shamsudin, M. N. (2013). Consumer willingness to pay for green food in Malaysia. Journal of International Food and Agribusiness Marketing, 25(1), 1-18.

Schiffman, L.G., \& Kanuk, L.L. (2004). Consumer behavior. Boston, MA, Pearson Prentice Hall.

Schiffman, L.G., Kanuk, L.L., \& Wisenblit, J. (2010). Consumer Behavior. 10 ${ }^{\text {th }}$ ed. Upper Saddle River, NJ, USA, Pearson Prentice Hall.

Shiu, E., Hair, J., Bush, R., and Ortinau, D., (2009).Marketing Research European Edition. McGraw-Hill higher Education, London UK, 329-469

Solomon, M., Bamossy, G., Askegaard, S., \& Hogg, M. K. (2006). Consumer Behaviour, A European Perspective. $3^{\text {rd }}$ ed. Pearson Education Ltd. Essex, 37-48.

Steg, L., \& Vlek, C. (2009). Encouraging pro-environmental behaviour, An integrative review and research agenda. Journal of Environmental Psychology, 29, 307-317.

Suki, N.M. (2015) Customer environmental satisfaction and loyalty in the consumption of green products, International Journal of Sustainable Development and World Ecology, 22(4), 292-301.

Synodinos, C., Bevan-Dye, A. L., \& De-Klerk, N. (2013). Influence of Conative attitudes towards green advertising on black Generation Y students' environmental behaviour. Mediterranean Journal of Social Sciences, 4(3), 17-24.

Tan, B. C., \& Lau, T.C. (2011). Green purchase behavior, examining the influence of green environmental attitude, perceived consumer effectiveness and specific green purchase attitude. Australian Journal of Basic and Applied Sciences, 5(8), 559-567.

Thogersen, J. (2006). Media attention and the market for green consumer products. Business Strategy and the Environment, 15(3), 145-156.

Van Doorn, J., \& Verhoef, P. C. (2011). Willingness to pay for organic products, Differences between virtue and vice foods. International Journal of Research in Marketing, 28, 167-180.

Vernekar, S.S, and Wadhwa, P. (2011). Green Consumption an Empirical Study of Consumers Attitudes and Perception regarding Eco-Friendly FMCG Products, with special reference to Delhi and NCR Region. Opinion. 1(1), 64-74.

Wahid, N.A., Rahbar, E., \& Tan, S. S. (2011). Factors influencing the green purchase behaviour of Penang environmental volunteers. International Business Management, 5(1), 38-49.

Young, W., Hwang, K., McDonald, S., \& Oates, C. J. (2010). Sustainable consumption, Green consumer behaviour when purchasing products. Sustainable Development, 18, 20-31.

Yusoff, M. S. B. (2011). Psychometric properties pf the learning approach inventory, A confirmatory factor analysis. Education in Medicine Journal, 3(2), 24-31.

Yusuf, S and Fatima, Z. (2015). Consumer Attitude and Perception towards Green Products. The International Journal of Indian Psychology, (2) 3, 141-146 
Zhu, Q. L. N., Geng, Y., \& Qi, Y. (2013). Green food consumption intention, behaviours and influencing factors among Chinese consumers. Food Quality and Preference, 28(1), 279-286.

Zhuang, W., Cumiskey, K. J., Xiao, Q., \& Alford, B. L. (2010). The impact of perceived value on behaviour intention, An empirical study. Journal of Global Business Management, 6(2), 1-7.

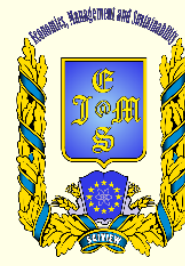

(c) 2016-2021, Economics, Management and Sustainability. All rights reserved.

This open access article is distributed under a Creative Commons Attribution (CC-BY) 4.0 license.

You are free to:

Share - copy and redistribute the material in any medium or format Adapt - remix, transform, and build upon the material for any

purpose, even commercially.

The licensor cannot revoke these freedoms as long as you follow the license terms.

Under the following terms:

Attribution - You must give appropriate credit, provide a link to the license, and indicate if changes were made.

You may do so in any reasonable manner, but not in any way that suggests the licensor endorses you or your use.

No additional restrictions

You may not apply legal terms or technological measures that legally restrict others from doing anything the license permits.

Economics, Management and Sustainability (ISSN: 2520-6303) is published by Scientific Publishing House "CSR",

Poland, EU and Scientific Publishing House "SciView", Poland

Publishing with JEMS ensures:

- Immediate, universal access to your article on publication

- High visibility and discoverability via the JEMS website

- Rapid publication

- Guaranteed legacy preservation of your article

- Discounts and waivers for authors in developing regions

Submit your manuscript to a JEMS at http://jems.sciview.net or submit.jems@sciview.net 